\title{
Pes Standardisation in 3D Geometric WAE Morphometrics: Ethics, Ownership, and Methods
}

Cara S. Hirst, Institute of Archaeology, University College London, 31-34 Gordon Square, London, WC1H OPY, UK

E-mail: cara.hirst.13@ucl.ac.uk

Suzanna White, Institute of Archaeology, University College London, 31-34 Gordon Square, London, WC1H OPY, UK

Sian E. Smith, Centre for the Forensic Sciences, University College London, 35 Tavistock Square, London, WC1H 9EZ, UK; Department of Security and Crime Science, University College London, 35 Tavistock Square, London, WC1H 9EZ, UK

\section{ABSTRACT}

The collection and analysis of 3D digital data is a rapidly growing field in archaeology, anthropology, and forensics. Even though the 3D scanning of human remains in archaeology has been conducted for over 10 years, it is still frequently considered as a new field. Despite this, the availability of 3D scanning equipment and the number of studies employing these methods are increasing rapidly, and it is arguably damaging to the validity of this field to continue to consider these methods new and therefore not subject to the same standardisations as other researches. This paper considers the current issues regarding the lack of standardisation in the methods, ethics, and ownership of 3D digital data with a focus on human remains research. The aim of this paper is to stimulate further research and discussion, allowing this field to develop, improving the quality and value of future research.

Résumé: La collecte et l'analyse des données numériques 3D constituent une méthode de plus en plus utilisée dans la recherche archéologique, anthropologique, médicolégale et médicale. Même si l'archéologie fait appel au balayage $3 D$ des restes humains depuis plus de dix ans, on considère toujours qu'il s'agit d'un domaine relativement jeune. Entendu que la disponibilité de l'équipement de balayage $3 \mathrm{D}$ et que le nombre d'études où cette méthode est utilisée grandissent, considérer à tort que ce domaine est nouveau et omettre conséquemment de le soumettre aux mêmes normes réglementaires que d'autres recherches ne fait rien pour établir sa validité. Le présent article porte sur les problèmes actuels liés au manque de normalisation des méthodes, règles d'éthique et droits d'exclusivité des 
données numériques 3D utilisées dans la recherche sur les restes humains, dans l'espoir d'ouvrir la voie à d'autres recherches et discussions favorisant le développement de ce champ et l'amélioration de la qualité et de la valeur de la recherche future.

Resumen: La recopilación y el análisis de datos digitales en 3D es un método de rápido crecimiento que se utiliza en investigacones arqueológicas, antropológicas, forenses y médicas. A pesar de que el escaneo de restos humanos en 3D ha sido utilizado en arqueología durante más de diez años, con frecuencia se lo considera como un campo nuevo. La disponibilidad de equipos de escaneo en 3D y el número de estudios que emplean este método están aumentando y es perjudicial para la validez de este campo el continuar considerándolo como un campo nuevo y que por lo tanto no esté sujeto a las mismas estandarizaciones que otros tipos de investigación. Este documento considera los problemas actuales causados por la falta de estandarización en los métodos, la ética y la propiedad de los datos digitales en 3D, con un enfoque en la investigación de restos humanos, con la esperanza de que esto de lugar a nuevas investigaciones y discusiones que permitan desarrollar este campo, mejorando la calidad y el valor de las investigaciones futuras.

\section{KEY WORDS}

3D digitising, Geometric morphometric, Standardisation, Ethics, Ownership, Observer error, Reconstruction

\section{Introduction}

3D digital data have been rapidly incorporated in archaeological and anthropological fields, and they are providing new and unlimited access to fragile and valuable remains. For instance, 3D digitisations can be used for facial reconstructions such as Robert the Bruce (Wilkinson et al. 2017), the creation of interactive virtual displays such as the Gebelein Man at the British Museum (Ynnerman et al. 2016), or 3D printed to reveal otherwise hidden trauma such as the Jericho skull (Hirst 2017). Additionally, 3D digitisations allow for more advanced statistical analysis of biological shapes, and the most commonly employed method in anthropology and archaeology is 3D geometric morphometrics. 3D geometric morphometrics (GMM) is an analytical method of quantifying and comparing 3D objects. 
GMM methods have been advancing over the last decade, such as with semi-landmark (Gunz and Mitteroecker 2013), and finite element analysis which predicts how a shape may respond to external forces (O'Higgins et al. 2011). These technological and statistical advancements have expanded this field, to the point where the 3D digitisation of archaeological material, including human remains, is a frequent occurrence, with many universities owning multiple 3D scanners as well as photogrammetry equipment which can be used to create 3D digital data. The proliferation of digitisation methods and equipment has resulted in the exponential growth of GMM analysis in human remains research. GMM studies of human remains include the analysis of biological and cultural variation, evolution, and adaptation (Archer and Braun 2010; Buchanan and O'Brien 2014; Cardillo 2010; Lawing and Polly 2010; Perez 2007). For instance, by utilising GMM analysis researchers have developed a more advanced understanding of sexual dimorphism and age-related morphological alterations in adult human skeletons (Bigoni et al. 2010; Franklin 2010; Gonzalez et al. 2009; Janin 2017; Viðarsdóttir et al. 2002). The empirical data that GMM provides increase the precision and robustness with which biological profiles of skeletal remains can be made.

Despite this, 3D digital data and GMM are still considered by some researchers as a relatively recent or new field (Adams et al. 2004; Marcus and Corti 1996; Rohlf 1999, 2002; Waddell 2014). While 3D digitisation and GMM methods have led to significant advancements in the analysis of human remains, the continued suggestion that these digitisation and analytical methods are novel arguably reduces the scientific rigour that would otherwise be applied to the field. While the standardisation of analytical methods and the reporting of data in archaeological, anthropological, and forensics research are strongly supported (Clark et al. 1966; Cunha et al. 2009; Falys and Lewis 2010; James and Thompson 2014; Karyda and Mitrou 2007; Lyman and VanPool 2009), there is a continued lack of standardisation regarding the digitisation, use, and analysis of $3 \mathrm{D}$ digital data (Pajas and Olivam 2009).

The requirement for standardisation is further amplified by the relative potential of 3D digital data compared to other data, such as written data or $2 \mathrm{D}$ visualisations. Unlike other forms of data collection, there is considerable potential for the reuse and sharing of 3D digital data. For instance, depending on the digitisation method, a digital collection of 3D cranial scans may be used for almost as many different types of studies as the original human remains, with the exception of destructive methods such as isotope analysis. This makes 3D digital data particularly valuable in archaeological studies, as the reuse and sharing of digital data has the potential to limit the damage on physical remains from repeated handling (see White et al., this issue). However, it is also these benefits that can result in 
significant scientific and ethical problems in a field that is considered new and therefore not subject to the standards and regulations that would otherwise be applied. Moreover, the proliferation of 3D printers makes the $3 \mathrm{D}$ reproduction of human remains, as well as other potentially culturally sensitive archaeological materials, increasingly accessible. The potential for reuse and the ability to create a physical replica, arguably necessitates the consideration of the ethics and ownership for 3D digital data, separate from other forms of visual digital data. Open discussion is required to develop standardisation of 3D digitisation for future research to increase the value of this growing field. With this aim, this paper will discuss the key areas where a lack of standardisation in GMM methods is having the greatest negative impact on archaeological research, and make suggestions for future research.

\section{Ethics of 3D Digital Data}

Currently, there is an alarming lack of ethical or legal guidance regarding $3 \mathrm{D}$ digital data. 3D digitisation provides an interactive digital representation that can be used to produce 3D-printed models, which significantly increases their data potential, compared to 2D photographic data or written data (Killgrove 2015; McMenamin et al. 2014). As such, 3D digital data arguably require separate consideration with regard to ethics, ownership, and research protocols. Therefore, discussions regarding the ethical and legal use of 3D digital data need to be held, and further research is needed in order to understand both the potential and possible negative impact of these data. This issue can be broken down into: understanding the general ethical considerations of digital data; ownership of these data; the preservation, long-term storage, and curation of these digital data; and the ethical implications of $3 \mathrm{D}$ digital data in cases of repatriation.

\section{Ethical Considerations}

While there are clear protocols regarding the curation and handling of human remains, currently there are few standardised ethical guidelines or research agreements regarding 3D digital data of human remains in archaeology (Cassman and Odegaard 2007; Giesen 2013; Marques-Grant and Fibiger 2011). Although some organisations are in the process of creating these guidelines such as the British Association of Biological Anthropology and Osteoarchaeology (BABAO) although these are restricted to Britain and the BABAO organisation (BABAO 2017). Furthermore, very few papers have discussed the ethical issues of $3 \mathrm{D}$ digital data of human 
remains (Márques-Grant and Errickson 2017), and yet digital datasets of archaeological material and human remains are ever expanding (Smithsonian 2016; Solly 2017). 3D digital data are also becoming more publicly accessible, with websites such as Sketchfab (2016), MorphoSource (2013), and Digitised Diseases (2013) offering open access to 3D data, and often downloadable content. The key to understanding the ethical requirements of 3D data, arguably lies in defining how 3D data differ from physical human remains and other digital data formats. Results from a survey by indicated that researchers and collection managers and curators generally considered 3D data to lie between photographic data and the original object with regard to ethics and ownership. However, more work is needed in order to determine what this middle ground between photographs and skeletal remains would entail when considering the ethics, ownership, and use of 3D digital data.

\section{Questions of Ownership}

Copyright and Intellectual Property Right (IPR) legislation (Jisc 2017) sets out the legal guidelines regarding the ownership of information and data, including 3D digital data. While academic work may be exempt from this for non-commercial research, this legislation states that images cannot be copied further or disseminated to other researchers or individuals. Despite this legal framework, there is still a lack of consensus concerning the ownership of 3D data specifically when digitising or physically replicating objects of cultural, societal, or religious value which are typically not copyrighted. For example, in 2014 there was a legal debate over the publication of a downloadable 3D scan of a public statue. A 3D photogrammetry model was made of the cast of Michelangelo's Moses sculpture that currently resides on the Augustana College Campus, Sioux Falls, USA (Bogle 2015a, b; Weinberg 2015). The college petitioned that the digital data be removed as the publisher had not sought the permission of the college or the sculptor. However, as the statue was not under copyright and in a public place, there was no legislation preventing the online publication of this material (Weinberg 2015). Heritage and artistic objects like this are regularly in public spaces and are accessible to members of the public for viewing, sketching, and photographing, etc.

As there is currently little overarching legislation or guidance with regard to the use and ownership of 3D data, it is up to individual institutions or organisations to put these terms and conditions in place. Legally, human remains are not considered the property of the curating institutions, apart from cases where the remains have been altered through the application of skill (Curtis 2003). As the ownership of archaeological 
human remains is not covered by legislation in the UK, the ownership of data collected from these remains is dependent on the terms and conditions established by the curating institution. MorphoSource, an online database of 3D digital data, states in their terms and conditions that in order to upload and share data, the individual must confirm that they have acquired permission from the curator or collection manager of the institute where they collected these data (MorphoSource 2013). This suggests that MorphoSource considers the collections manager or curator of the object from which a digitisation is made to hold at least partial ownership of the 3D data; however, this does not prevent the creation of independent digital data stores. Several museums do have specific guidelines regarding the collection, ownership, and use of photographic data from their collections. The Museum of London, for instance, states that the copyright for all photographs taken from the collections is held by the Museum of London and may not be reproduced (Museum of London Human Remains Working Group 2011). However, from the survey only 33\% $(n=52)$ had a research agreement that included 3D data, while 71\% $(n=52)$ had agreements which covered photographic data. As such the 3D digitisation of human remains from museums or other archaeological collections may not be subject to the same terms and conditions as photographs, online collections, or simply the direct sharing of data between individuals.

When surveyed, 23\% $(n=49)$ of collection managers and curators stated that they considered the curating institution to own these data, while only $6 \%(n=49)$ considered the researcher to own the data. However, when researchers were surveyed $38 \%$ stated that they believed they were the owner of any digital data they created, with only $8 \%(n=26)$ considering the curating institution to own these data. As demonstrated in the cases of Michelangelo's Moses sculpture, when ownership of 3D digital data is unclear, this can result in conflict; as such it is argued that research agreements regarding the ownership of these data are essential. Joint ownership of 3D digital data may be a democratic approach, with $33 \%$ of curation and collection managers $(n=49)$ and $54 \%$ of researchers $(n=26)$ considering digital data to be jointly owned by both the curating institution and the researcher. However, ownership in itself is a complicated issue and any guidelines or research agreements should state ownership in terms of practical applications to avoid misunderstandings and misuse of data.

The topic of ownership becomes more complicated when it is considered that copyright or research agreement may be voided when physical objects or digital data are altered through the application of skill; therefore, reconstructed scans may no longer be under copyright or ownership (either full or partial) of curating institutions (Department for Culture, Media and Sport 2005, 12). Additionally, there is legal precedent for copyright to be voided by small alterations to $3 \mathrm{D}$ digital data and prints, although these 
cases did not involve archaeological material or human remains (Thompson 2017). Moreover, depending on the method used to create 3D scans, the raw data may already be sufficiently altered in the 3D digitisation process. For instance, depending on the element being digitised, several individual scans may be taken with a laser scanner. To create the final $3 \mathrm{D}$ surface model, extraneous objects must be removed, the individual scans must be manually merged together into a single model, and the surface of the model may need to be smoothed and altered. At present, it is unknown how such changes may affect legal decisions regarding copyright. As such, legal advice needs to be sought to determine at what point an image may be considered sufficiently altered through skill to void copyright, and further research is required to fully determine the IPR concerning 3D data in different states and alterations, as well as to determine the rights of curating institutions and researchers, and to then create legislation which protects these rights.

\section{Preservation of Physical Remains}

One of the benefits of 3D digital data is the storage and preservation of physical remains; this is particularly true if the digital data have high accuracy making them comparable to the originals. While archaeological collections are not subject to the UK Human Tissue Act or European Tissues and Cells Directives (HTA Human Tissue Authority 2016), there are several documents that outline guidance for the care of human remains in museums (Department for Culture, Media and Sport 2005); however, 3D digital collections of human remains are not currently included in such guidelines. As such, researchers may have hundreds of 3D digital data in their possession, and the storage, use, and sharing of these data may be entirely at their own discretion. There are three key issues concerning storage of digital data that arguably requires consideration: preserving data, securing data, and cases where 3D scans should potentially be destroyed following completion of research.

One of the key duties of any institution that holds human remains is the preservation of the material, as this will also have an impact on future research. Digitisation provides a potential back-up for physical remains; while obviously not a replacement, if the original human remains are damaged or destroyed, then 3D scans would be the next best resource available. There have been numerous cases of the loss or damage of vitally important museum collections. For example, during World War II, 200 Homo Erectus fossils were sent to the USA for safekeeping; however, the fossils went missing before they reached the USA (Etler 1996). London air raids in 1940-1941 severely damaged the Natural History Museum and Royal Col- 
lege of Surgeons, and many specimens were damaged or destroyed (Fforde 1992; Natural History Museum 2015). Even in everyday data collection, there is always the risk of damage; repeated handing, even where all measures of care are taken, results in an accumulation of damage to the material over time (Fletcher et al. 2014; Palmer 2015). For instance, a study conducted by Bowron $(2001,2003)$ analysed taphonomic damage from six skeletal collections and determined that the two factors which most significantly affected the preservation of human remains in a collection were handling and packaging. Online stores and published skeletal recording sheets have been promoted, as they can be used by multiple researchers, and limit the handling of remains and subsequent damage to material (Fletcher et al. 2014; Gröning et al. 2005; Palmer 2015; Pelfer and Pelfer 2003). In addition, to further preserve skeletal material it would be beneficial, where possible, for researchers to utilise existing 3D scans rather than subjecting the remains to repeated scanning and/or handling (Wilson 2014-16). It would therefore be valuable for details of the scans and scanning process to be compiled between the original researcher and the curating institution, and stored in a format that makes these data available for future research, while acknowledging the contribution of the original collector.

In the last 2 years, the ownership and use of digital data have been discussed (Decker and Ford 2017; Márques-Grant and Errickson 2017; Niven and Richards 2017). However, more research is needed to determine the potential of sharing these digital collections. Furthermore, researchers may frequently collect data from archaeological and anthropological collections internationally, and as such it is argued that international agreements regarding the storage of $3 \mathrm{D}$ digital data are required.

\section{Special Considerations: Repatriation and Cultural Sensitive Remains}

The ascribed cultural and religious views of human remains and digital or physical replicas of human remains vary significantly. As such it is important to consider potential variation in ethical issues of collecting, storing, sharing, and displaying 3D digital data, as there may be cases where it is not ethical to keep digital copies of human remains. A common argument for scanning human remains is to allow repatriation requests to be honoured, while still keeping a digital copy of these data to be utilised for further research (Mathys et al. 2013; Rowe et al. 2002; Schurmans et al. 2002). Nevertheless, no research could be found in which the organisations and communities actively making repatriation requests were consulted with regard to their views on retaining 3D scans of human remains after repatriation. For instance, a study conducted by Henson (2015) evaluated the 
benefit of different 3D scanning technologies to preserve osteological data before repatriation. For their study human remains from Clover and Fort Ancient in West Virginia, USA, were scanned using different methods prior to their repatriation. The paper failed to specify if the work was conducted in collaboration with NAGPRA (NAGPRA 1990; National Park Service 2018) or if ethical approval was given or sought. While it may well be the case that the author received approval from NAGPRA and/or the descendant communities of this site, it would have been pertinent to detail this agreement and how these 3D digital data were to be used or stored in the future. Instead, this study focused on demonstrating that it was possible to create a high-resolution model of NAGPRA-protected Native American remains in the time period available for archaeological research prior to repatriation, and ignored arguably the more pertinent question of whether these digital data be created and stored.

Previous instances where archaeological material has been digitised and printed without approval of the group requesting repatriation have resulted in controversy. In another case, the 3D scanning and printing of seven columns from the Old Summer Palace in Beijing by artist Oliver Laric has caused controversy. The columns are currently held in Norway, although it has been agreed that they will be repatriated to China. As such, the production of these 3D prints has been argued as an attempt to steal cultural heritage material (Mendoza 2014). These case studies demonstrate the disparity between the differing views of researchers and the groups advocating for the repatriation of archaeological material. Given these controversies alongside the current dearth of ethical consideration of digitising repatriated or culturally sensitive remains, promoting the scanning of such material without the discussion of approval or detailing the future use of these digital data may lead to actions in the future that could damage the integrity of this discipline.

Despite the paucity of research, there are some localised protocols currently in existence. The National Museums of Liverpool recognise the cultural sensitivity of some items, including photographs and other depictions of human remains, and that some forms of analysis, such as photography and X-rays, may not be appropriate due to issues of cultural significance (National Museums Liverpool 2017). Similarly, the Museums Galleries of Scotland suggest that, after repatriation requests have been accepted, decisions regarding the treatment of the remains, such as photography, are the responsibility of the group or individuals requesting the repatriation $(\mathrm{Mu}-$ seums Galleries Scotland 2017). It is clear that the potential repatriation of digital data is a concern among researchers, with Weiss (2001) noting the potential negative effect of digital data or casts coming under repatriation acts, due to the catastrophic loss of data. 
Additionally, among some cultures distinctions are not made between original sacred or culturally affiliated objects, and replicas or even photographs (Brown and Nicholas 2012; Isaac 2015). Furthermore, in cases of repatriation of cultural items, digital scans have been used instead of the original item (Hess et al. 2009; Resta et al. 2001), indicating a stronger relationship or at least a blurred line between digital data and the physical material. It is therefore argued that further research is necessary to determine the ethical responsibilities when storing or collecting digital copies of human remains or other culturally sensitive items. This is a discussion that needs to happen between archaeological institutes and the communities and organisations who are requesting the repatriation of human remains. It is suggested that the relevant communities/organisations should be consulted prior to the scanning and/or sharing of culturally sensitive material. It is arguably unethical or unbeneficial for future collaboration between human remains research and indigenous communities to keep digital versions of human remains without the knowledge of these organisations.

\section{Standardisation of Methods}

As previously stated one of the key advantages of $3 \mathrm{D}$ digitisation is that once a skeletal element has been scanned, the digitisation can be used by numerous researchers in a variety of studies. While there are important ethical and legal considerations for this practice, as discussed, the digitisation of skeletal remains opens the possibility of a worldwide dataset, promoting a more holistic/global approach to digital data which will maximise the availability of resources, preserve the original material, and foster greater collaboration among researchers (see White et al., this issue). There are already a number of different institutions who are compiling extensive 3D scanned data collections of human and animal remains (e.g. Smithsonian 2016). However, in many cases within human remains research, the value of pre-existing databases of published papers has been limited by the lack of standardisation in data collection and the data format; as such, standardising these digital databases may increase their potential for future research and global collaborations. Two components of method standardisation shall be discussed in this paper: digitisation methods and landmark placement for GMM analysis in terms of error assessment.

\section{Data Collection Methods}

There are several methods which produce 3D models such as photogrammetry, structured light scanning, laser scanning, computed tomography 
(CT) scanning, and magnetic resonance imaging (MRI). While these methods all produce a 3D digitisation, the quality and resolution of the data varies across the different technologies and methodologies. Although several papers have discussed the variation in accuracy and resolution for different scanning technologies (see White et al., this issue), this has not yet led to the introduction of standardised digitisation methods (Boehler et al. 2003).

There are many factors that influence the quality of the 3D data. The Next Engine Desktop laser scanner, for instance, has several different settings which relate to the object distance and size and influence the quality of the scan, and may influence the reliability of consistently placing GMM landmarks (Kuzminsky and Gardiner 2012; Slizewski et al. 2010; ZaimovicUzunovic and Lemes 2010). The practical implication of differences in scanning accuracy will also depend on the purpose of the research and nature of the material involved. For instance, Villa et al. (2017) compared the accuracy of 3D models generated from three different laser scanners and software, finding no significant variation in the topography of the bone surface between different scanners, although each scanner introduced random error which influenced curvature values. While the choice of digitiser may be dictated by their availability in an institution or by research grants provided, the information regarding the technology and process involved in creating a digitisation, if provided, can also act to increase the potential of reuse for these collections. Therefore, it is recommended that, when publishing digital collections, researchers include details of the digitisation material and method, allowing this to be both easily reproducible and to enabling valuable comparisons between digital data.

In addition, researchers will frequently record other data from the human remains with 3D scanning, including age, sex, and stature estimation, and the presence of pathology. If these data are not available in addition to 3D scans, then the benefit to both researchers and curators is reduced. Therefore, when possible, individual researchers and curators should consider the future value of their scans in a wider context, not only to themselves but also to the greater scientific community. By creating a standard for 3D data collection, regarding the quality and completeness of the scan, as well as the secondary data obtained for each specimen, the value of this method as a reproducible multi-user dataset can be conserved.

\section{Placing Landmarks}

Many different methods can be used to analyse 3D digital data. The method most frequently employed in human remains studies is geometric 
morphometrics (GMM), which typically involves the use of landmarks and/or semi-landmarks. GMM studies use these points to record the morphology of anatomical features in order to quantify biological shapes, and the $3 \mathrm{D}$ coordinate data can easily be exported for analysis. While this is a very valuable method that can be easily reproduced, there are some potential issues concerning the standardisation of the landmarks utilised and the descriptions of these landmarks. When determining the landmarks for a study, several factors need to be considered, including the preservation of the sample and the biological questions being asked. However, even among studies which are asking the same biological question of the same skeletal element, there is considerable variation in the number and position of landmarks which are being utilised (Bigoni et al. 2010; Kimmerle et al. 2008). The lack of standardisation in the landmarks employed by GMM studies has created issues when attempting to make comparisons between studies.

GMM is no longer a fledgling field within archaeology and now is the time to discuss ways to standardise analysis. There are many examples in archaeological methods where standardisation of the field has occurred late in its development, which has significantly limited the value of earlier studies (Florian 1990; Musonda 1990; Oonk et al. 2009; Pajas and Olivam 2009). For instance, methods for recording dental caries have varied significantly between studies, limiting the ability to compare across studies preventing comparisons (Cox and Mays 2000; Hillson 2001; Whittaker and Molleson 1996).

This is not to say that the validity of landmarks should be compromised in the aim of standardisation; instead, it is suggested here that efforts should be made to standardise the points used when designing the GMM methodology. Not only would the standardisation of landmarks increase the possibility for direct comparison of results between studies, but researchers could also publish their raw landmark coordinate data online as a dataset, allowing other researchers to directly incorporate these data into their own analysis. It is suggested that such raw coordinate data would not be subject to the same ethical and legal considerations as 3D scans, as these data are considered sufficiently different from the raw material and instead are more similar to measurements or the scoring of biological features, such as those used in sex estimation.

\section{Assessing Error}

There is, however, a lack of standardised methods for observer error in GMM research, which limits the ability to compare methods and studies (Fields et al. 1995). This error may be introduced during the digitisation 
process, or in the extraction of coordinate data such as landmarks for analysis. When considering the error introduced during digitisation, some research indicates that observer error in methods such as photogrammetry (Weinberg 2006), as well as 3D digitisers and laser scanning (Sholts et al. 2011), leads to non-significant levels of observer error, although potentially higher than those found in traditional methods, due to the nature of the process (Hildebolt and Vannier 1988). There are also indications that observer error may be affected by experience with the equipment (Sholts et al. 2011), although this would also be expected with more traditional methods.

Measurement error is inevitable regardless of the method used, due to human error as well as issues associated with the measuring equipment (Barker et al. 1994; Choi et al. 2002). Assessment of observer error is difficult in 3D GMM, as it requires the direct comparison of 3D data that exist in different coordinate systems (Richtsmeier et al. 2002; von Cramon-Taubadel et al. 2007). Typically, data in the form of 3D landmarks are registered using processes such as generalised Procrustes analysis (GPA) (Gower 1975), although this does not make variability due to observer error directly quantifiable (Richtsmeier et al. 2002). Despite this, several GMM studies have analysed error after processing landmark data with GPA and principal component analysis (PCA) (for example: Franklin et al. 2006, 2007; Kranioti et al. 2009; Lockwood et al. 2002; Terhune et al. 2007). For instance, a study conducted by Franklin et al. (2006) assessed intra-observer error by placing landmarks six times, aligning the configurations through GPA, and performing PCA. It was determined, based on the clustering of repeat configurations for principal components $1-5$, that intra-observer error was "unlikely to have unduly influenced the results" (Franklin et al. 2006, p. 16). A similar analysis was conducted by Kranioti et al. (2009) where intra-observer error was determined to be low enough due to distance between repeats being lower than distance between individual data points. However, GPA-registered data resulted in error being distributed randomly across the configuration, in a phenomenon referred to as the Pinocchio effect, as such methods are not suitable for assessing error (Chapman 1990; von Cramon-Taubadel et al. 2007; Zelditch et al. 2012).

Researchers have developed a wide range of methods to quantify and assess levels of observer error. These include plotting the results of PCA to visually assess how tightly clustered repeat data points are (Dryden and Mardia 1998; O'Higgins and Jones 1998), the comparison of intra-individual distances to inter-individual distances (Lockwood et al. 2002), analyses of variance (ANOVA) (Freidline et al. 2015; Nicholson and Harvati 2006; Ross and Williams 2008), calculation of intra-class correlation coefficients (Fourie et al. 2011; Weinberg 2006), and technical error of measurement values (Weinberg 2006). Finally, at present there is no standard of accept- 
able observer error (von Cramon-Taubadel et al. 2007). Different thresholds have been suggested, ranging from $0.5 \mathrm{~mm}$ or less (Guyomarc'h et al. 2012) to $1 \mathrm{~mm}$ or less (Weinberg 2006); however, as error must be considered in terms of relative significance of effect on the results, it is unlikely that an acceptable standardised error threshold will be established. Further discussion as to how to determine acceptable error is still sorely needed, even if this may not be applicable to all studies.

\section{Reconstruction}

One of the greatest problems facing archaeology is limited preservation, which confines sample sizes and research capabilities (Benazzi and Senck 2011). This is particularly the case with GMM, because the landmarks utilised must be present on the entire sample (Bookstien 1991). It is important therefore to be able to reconstruct missing data to allow for morphological analysis or other forms of analysis such as facial reconstruction for victim identification in forensic investigations (Benazzi and Senck 2011; Benazzi et al. 2009; Krogman and Iscan 1986; Ponce De León and Zollikofer 1999; Wilkinson and Neave 2003). As such the ability to digitally reconstruct damaged, distorted, or fragmented objects is of great value in $3 \mathrm{D}$ research.

Despite the numerous benefits of digital (or virtual) reconstructions, these methods obviously introduce error. Furthermore, the accuracy of these reconstructions has been found to vary significantly between reconstruction methods and the nature of the study material (Benazzi et al. 2009; Hirst 2016). This is illustrated in a study conducted by Arbour and Brown (2014) which compared four reconstruction methods among five different specimens shown in Figure 1. To develop a standardised method for assessing error in GMM studies, it is important to examine the variety of methods that have been used in previous GMM studies, and assess the validity of these methods. However, the ability to compare reconstruction methods is arguably further hindered by the lack of standardisation in how studies present error. By creating standardised error assessment methods, researchers will be able to more accurately compare available literature on reconstruction methods. Until then, the reliability and validity of the results of this field remain somewhat questionable. 


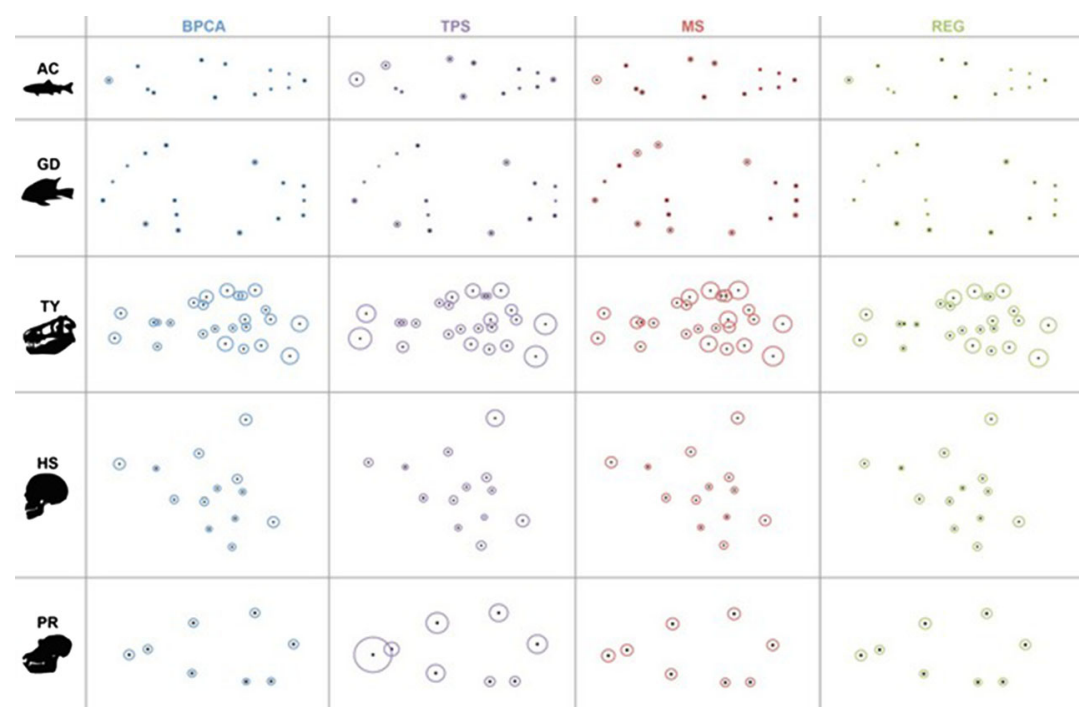

Figure 1. The accuracy of reconstruction methods, the circle radius indicates the mean error in reconstruction (Arbour and Brown 2014)

\section{Recommendations}

After reviewing the above issues of ethics, digitisation methods, and error assessment, the following recommendations can be made for future researchers conducting 3D digitisation of human remains:

1. Clear international ethical guidelines are required: these should describe uses in practical terms and avoid vague language such as ownership; these should also account for the potential of 3D digital data to be changed and altered.

2. Organisations and communities involved in the repatriation of human remains should be included in future discussions regarding the digitisation of these remains, to develop guidelines. These guidelines should reflect the potential cultural variation between countries and communities regarding ethical treatment of human remains.

3. Future studies which digitise culturally sensitive remains or remains in anticipation of repatriation should require ethical approval from the organisation/community to whom the remains will be repatriated. This approval and a discussion of the future use of these digital data should be clearly stated in any publications.

4. Further research is needed in order to determine how to maximise the future potential of 3D digital collections. 
5. A review of previously published papers is needed in order to investigate the variation in landmarks used in GMM studies and to create a standardised landmark system which will maximise the potential of coordinate data, and allow direct comparisons between studies.

6. A standardised method of assessing error needs to be created, and decisions made on the threshold for what may be considered as a reasonable amount of error for digitisation methods, the placement of landmarks or other coordinate data, and the reconstruction or estimation of missing data.

\section{Conclusion}

This paper has discussed the current lack of standardisation regarding the ethics and ownership of 3D data, as well as 3D data collection and analysis, with regard specifically to the analysis of human remains. It is hoped that this will lead to further discussions resulting in a standardised approach to 3D data collection, use, and ownership, and assessment of error in 3D data analysis within archaeological research. Future studies that explicitly evaluate the current methods for assessing error in GMM results are required to determine the best approach for future research. Before a standardised approach can be suggested, it is necessary to understand how different institutions and cultures view 3D scans of human remains, which we suggest should be achieved through collaboration between institutions, researchers, and relevant individuals. These discussions need to be started, while the field is still developing, in order to avoid the problems that have already hindered archaeological research in the past due to the difficulty in comparisons across studies and to prevent results from losing their value due to a lack of standardisation. We therefore argue that cross-disciplinary research, involving anthropologists, archaeologists, bioethicists, and legal scholars, is needed to consider these ethical questions and to develop suitable guidelines of proper practice.

\section{Compliance with Ethical Standards}

Conflict of interest The authors declare that they have no conflict of interests. 


\section{Open Access}

This article is distributed under the terms of the Creative Commons Attribution 4.0 International License (http://creativecommons.org/licenses/by/4. $0 /$ ), which permits unrestricted use, distribution, and reproduction in any medium, provided you give appropriate credit to the original author(s) and the source, provide a link to the Creative Commons license, and indicate if changes were made.

\section{References}

Adams, D., Rohlf, J., \& Slice, D.

(2004). Geometric morphometrics: Ten years of progress following the 'revolution'. Italian Journal of Zoology, 71, 5-16.

Arbour, J., \& Brown, C.

(2014). Incomplete specimens in geometric morphometric analyses. Methods in Ecology and Evolution, 5, 16-26.

Archer, W., \& Braun, D.

(2010). Variability in bifacial technology at Elandsfontein, Western cape, South Africa: A geometric morphometric approach. Journal of Archaeological Science, 37(1), 201-209.

Barker, T. M., Earwaker, W. J. S., \& Lisle, D. A.

(1994). Accuracy of stereolithographic models of human anatomy. Australasian Radiology, 38(2), 106-111. https://doi.org/10.1111/j.1440-1673.1994.tb00 146.x.

Benazzi, S., \& Senck, S.

(2011). Comparing 3-dimensional virtual methods for reconstruction in craniomaxillofacial surgery. Journal of Oral and Maxillofacial Surgery, 69(4), 1184-1194.

Benazzi, S., Stansfield, E., Kullmer, O., Fiorenza, L., \& Gruppioni, G.

(2009). Geometric morphometric methods for bone reconstruction: The mandibular condylar process of Pico della Mirandola. The Anatomical Record, 292, 1088-1097.

Bigoni, L., Veleminska, J., \& Bruzek, J.

(2010). Three-dimensional geometric morphometric analysis of cranio-facial sexual dimorphism in a Central European sample of known sex. HOMOJournal of Comparative Human Biology, 61(1), 16-32.

BABAO.

(2017). Ethics and Standards. Retrieved August 9, 2018 from http://www.babao. org.uk/publications/ethics-and-standards/. 
Boehler, W., Vincent, M. B., \& Marbs, A.

(2003). Investigating laser scanner accuracy. The International Archives of Photogrammetry, Remote Sensing and Spatial Information Sciences, 34(5), 686-701.

Bogle, A.

(2015a). 3-D printer copying of sculptures: Is it legal? The Charlotte Observer. Retrieved August 4, 2018 from https://www.charlotteobserver.com/new s/politicsgovernment/article9493484.html.

(2015b). Good news: Replicas of 16th-century sculptures are not off-limits for 3-D printers. Slate. Retrieved March 17, 2018 from http://www.slate.co m/blogs/future_tense/2015/01/26/_3_d_printing_and_copyright_replicas _of_16th_century_sculptures_are_not.html?via=gdpr-consent.

Bookstien, F. L.

(1991). Morphometric tools for landmark data: Geometry and biology. Cambridge: Cambridge University Press.

Bowron, E.

(2001). MA Dissertation: Handling and packaging of human skeletal remains: Principles and practice. Durham: Department of Archaeology, University of Durham.

(2003). A new approach to the storage of human skeletal remains. The Conservator, 27, 95-106.

Brown, D., \& Nicholas, G.

(2012). Protecting indigenous cultural property in the age of digital democracy: Institutional and communal responses to Canadian First Nations and Māori heritage concerns. Journal of Material Culture, 17(3), 307-324.

Buchanan, B., \& O'Brien, M.

(2014). Continent-wide or region-specific? A geometric morphometrics-based assessment of variation in Clovis point shape. Archaeological and Anthropological Sciences, 6(2), 145-162.

Cardillo, M.

(2010). Some applications of geometric morphometrics to archaeology. Morphometrics for Nonmorphometricians, 124, 325-341.

Cassman, V., \& Odegaard, N.

(2007). Human remains: Guide for museums and academic institutions. Lanham: Altamira Press.

Chapman, R. E.

(1990). Conventional procrustes approaches. In F. Rohlf \& F. Bookstein (Eds.), Proceedings of the Michigan morphometrics workshop (Vol. 2). Ann Arbor: The University of Michigan Museum of Zoology. 
Choi, J. Y., Choi, J. H., Kim, N. K., Kim, Y., Lee, J. K., Kim, M. K., Lee, J. H., \& Kim, M. J. (2002). Analysis of errors in medical rapid prototyping models. International Journal of Oral and Maxillofacial Surgery, 31(1), 23-32. https://doi.org/10.1054/ijom.2000 .0135 .

Clark, J. D., Cole, G. H., \& Isaac, G. L.

(1966). Precision and definition in African archaeology. The South African Archaeological Bulletin, 21(83), 114-121.

Cox, M., \& Mays, S.

(2000). Human osteology: In archaeology and forensic science. Cambridge: Cambridge University Press.

Cunha, E., Baccino, E., Martrille, L., Ramsthaler, F., Prieto, J., Schuliar, Y., Lynnerup, N., \& Cattaneo, C.

(2009). The problem of aging human remains and living individuals: A review. Forensic Science International, 193(1-3), 1-13.

Curtis, $\mathrm{N}$.

(2003). Human remains: The sacred, museums and archaeology. Public Archaeology, 3(1), 21-32. https://doi.org/10.1179/pua.2003.3.1.21.

Decker, S., \& Ford, J. (Eds.).

(2017). Management of 3D image data. London: Academic Press.

Department for Culture, Media and Sport.

(2005). Guidance for the Care of Human Remains in Museums. https://www.brit ishmuseum.org/pdf/DCMS\%20Guide.pdf.

Digitised Diseases.

(2013). Digitised diseases. Retrieved March 15, 2018 from http://www.digitiseddi seases.org/alpha/.

Dryden, I. L., \& Mardia, K. V.

(1998). Statistical shape analysis. Chichester: Wiley-Blackwell.

Etler, D.

(1996). The Fossil evidence for human evolution in Asia. Annual Review of Anthropology, 25, 275-301.

Falys, C. G., \& Lewis, M. E.

(2010). Proposing a way forward: A review of standardisation in the use of age categories and ageing techniques in osteological analysis (2004-2009). International Journal of Osteoarchaeology, 21(6), 704-716.

Fforde, C.

(1992). The Royal College of surgeons of England: A brief history of its collections and a catalogue of some current holdings. World Archaeological Bulletin, 6, 22-31. 
Fields, S. J., Spiers, M., Hershkovitz, I., \& Livshits, G.

(1995). Reliability of reliability coefficients in the estimation of asymmetry. American Journal of Physical Anthropology, 96, 83-87.

Fletcher, A., Antoine, D., \& Hill, J. D.

(2014). Regarding the dead: Human remains in the British Museum. London: The British Museum Press.

Florian, M.

(1990). Scope and history of archaeological wood. Advances in Chemistry Series, $225,1-32$.

Fourie, Z., Damstra, J., Gerrits, P. O., \& Ren, Y.

(2011). Evaluation of anthropometric accuracy and reliability using different three-dimensional scanning systems. Forensic Science International, 207(1-3), 127-134. https://doi.org/10.1016/j.forsciint.2010.09.018.

Franklin, D.

(2010). Forensic age estimation in human skeletal remains: Current concepts and future directions. Legal Medicine, 12(1), 1-7.

Franklin, D., Freedman, L., Milne, N., \& Oxnard, C. E.

(2006). A geometric morphometric study of sexual dimorphism in the crania of indigenous southern Africans. South African Journal of Science, 102, 229238.

Franklin, D., O’Higgins, P., Oxnard, C. E., \& Dadour, I.

(2007). Sexual dimorphism and population variation in the adult mandible: forensic applications of geometric morphometrics. Forensic Science Medical Pathology, 3, 15-22.

Freidline, S. E., Gunz, P., \& Hublin, J. J.

(2015). Ontogenetic and static allometry in the human face: Contrasting Khoisan and Inuit. American Journal of Physical Anthropology, 158(1), 116131. https://doi.org/10.1002/ajpa.22759.

Giesen, $M$.

(2013). Curating human remains: Caring for the dead in the United Kingdom. Woodbridge: Boydell Press.

Gonzalez, P. N., Bernal, V. S., \& Perez, I.

(2009). Geometric morphometric approach to sex estimation of human pelvis. Forensic Science International, 189(1-3), 68-74.

Gower, J. C.

(1975). Generalized procrustes analysis. Psychometrika, 40(1), 33-51.

Gröning, F., Kegler, F., \& Weniger, G. C.

(2005). TNT-The Neanderthal Tools: Providing an online database and collaboration platform for neanderthal research. Mettmann: Neanderthal Museum. 
Gunz, P., \& Mitteroecker, P.

(2013). Semilandmarks: a method for quantifying curves and surfaces. Hystrix, the Italian Journal of Mammalogy, 24(1), 103-109.

Guyomarc'h, P., Santos, F., Dutailly, B., Desbarats, P., Bou, C., \& Coqueugniot, H.

(2012). Three-dimensional computer-assisted craniometrics: A comparison of the uncertainty in measurement induced by surface reconstruction performed by two computer programs. Forensic Science International, 219(1-3), 221-227. https://doi.org/10.1016/j.forsciint.2012.01.008.

Henson, K., Constantino, P., \& Freidin, N.

(2015). Stories in bones still told: Digitization of the clover site, fort ancient human remains. In The 84th Annual Meeting of the American Association of Physical Anthropologists (Vol. 156, p. 164).

Hess, M., Robson, S., Millar, F., \& Were, G.

(2009). Niabara: The Western Solomon Islands War Canoe at the British Museum: 3D documentation, virtual reconstruction and digital repatriation. In 15th International Conference on Virtual Systems and Multimedia (pp. 41-46).

Hildebolt, C. F., \& Vannier, M. W.

(1988). Three-dimensional measurement accuracy of skull surface landmarks. American Journal of Physical Anthropology, 76(4), 497-503. https://doi.org/ 10.1002/ajpa.1330760409.

Hillson, S.

(2001). Recording dental caries in archaeological human remains. International Journal of Osteoarchaeology, 11, 249-289.

Hirst, C.

(2017). British Museum Exhibition Review: The Jericho Skull, Creating and Ancestor. Papers from the Institute of Archaeology, 27(1), 1-4.

Hirst, C. S.

(2016). Reconstructing 3D scans: Increasing digital archaeological samples. Paper presented at the WAC-8, Kyoto, Japan.

HTA Human Tissue Authority.

(2016). EU Tissue and Cells Directives. Retrieved August 1, 2018 from https://www.hta.gov.uk/policies/eu-tissue-and-cells-directives.

Isaac, G.

(2015). Perclusive alliances: Digital 3-D, museums, and the reconciling of culturally diverse knowledges. Current Anthropology, 56(S12), S286-S296.

James, E., \& Thompson, J.

(2014). On bad terms: Problems and solutions within zooarchaeological bone surface modification studies. The Journal of Human Palaeoecology, 20(1), 89-103. 
Janin, G. K.

(2017). Sex estimation of non-adults: can it be done? A geometric morphometric approach. Paper presented at the MORPH17, Aarhus, Denmark.

Jisc.

(2017). 3D-digitisation-and-intellectual-property-rights. Retrieved February 20, 2018 from https://www.jisc.ac.uk/guides/3d-digitisation-and-intellectualproperty-rights.

Karyda, M., \& Mitrou, L.

(2007). Internet forensics: Legal and technical issues. In Second International Workshop on Digital Forensics and Incident Analysis (WDFIA 2007) (pp. $3-12)$.

Killgrove, K.

(2015). How 3D printed bones are revolutionizing forensics and bioarchaeology. Forbes. Retrieved December 17, 2017 from https://www.forbes.com/sites/ kristinakillgrove/2015/05/28/how-3d-printed-bones-arerevolutionizing-for ensics-and-bioarchaeology/\#13b955641a39.

Kimmerle, E., Ross, A., \& Slice, D.

(2008). Sexual dimorphism in America: geometric morphometric analysis of the Craniofacial region. Journal of Forensic Science, 53(1), 54-57.

Kranioti, E., Baastir, M., Sanchez-Meseguer, A., \& Rosas, A.

(2009). A geometric-morphometric study of the cretan humerus for sex identification. Forensic Science International, 189, 1-3.

Krogman, W. M., \& Iscan, M. Y.

(1986). The human skeleton in forensic medicine. Springfield: Charles C. Thomas.

Kuzminsky, S., \& Gardiner, M.

(2012). Three-dimensional laser scanning: Potential uses for museum conservation and scientific research. Journal of Archaeological Science, 39(8), 2744-2751.

Lawing, A. M., \& Polly, P. D.

(2010). Geometric morphometrics: Recent applications to the study of evolution and development. Journal of Zoology, 280(1), 1-7.

Lockwood, C. A., Lynch, J. M., \& Kimbel, W. H.

(2002). Quantifying temporal bone morphology of great apes and humans: An approach using geometric morphometrics. Journal of Anatomy, 201(6), 447-464.

Lyman, R. L., \& VanPool, T.

(2009). Metric data in archaeology: A study of intra-analyst and inter-analyst variation. American Antiquity, 74(3), 485-504. 
Marcus, L. F., \& Corti, M.

(1996). Overview of the new, or geometric morphometrics. In L. F. Marcus, M. Corti, A. Loy, G. J. P. Naylor, \& D. E. Slice (Eds.), Advances in morphometrics (pp. 1-3). New York: Plenum.

Márques-Grant, N., \& Errickson, D. (Eds.).

(2017). Ethical considerations: An added dimension. London: Academic Press.

Marques-Grant, N., \& Fibiger, L.

(2011). The Routledge Handbook of Archaeological Human remains and Legislation: An International guide to laws and practice in the excavation and treatment of archaeological human remains. New York: Routledge.

Mathys, A, Lemaitre, S., Brecko, J., \& Semal, P.

(2013). Agora 3D: evaluating 3D imaging technology for the research, conservation and display of museum collections. Antiquity 87(336).

McMenamin, P., Quayle, M., \& McHenry, C.

(2014). The production of anatomical teaching resources using three-dimensional (3D) printing technology. Anatomical Sciences Education, 7(6), 479-486.

Mendoza, $\mathrm{H}$.

(2014). 3D printing of Chinese cultural artifacts causes controversy. Retrieved November 8, 2017 from https://3dprint.com/6048/3d-printing-chineseartifacts/.

MorphoSource.

(2013). MORPHO SOURCE. Retrieved April 10, 2018 from http://morphosourc e.org/.

Museum of London Human Remains Working Group.

(2011). Policy for the care of human remains in Museum of London Collections. Retrieved April 12, 2018 from https://www.museumoflondon.org.uk/app lication/files/5714/8129/0350/Museum_of_London_Policy_for_the_Care_ of_Human_Remains.pdf.

Museums Galleries Scotland.

(2017). Introduction to Human remains in Museums. Retrieved April 12, 2018 from https://www.museumsgalleriesscotland.org.uk/advice/collections/int roduction-to-human-remains-in-museums/.

Musonda, F.

(1990). African archaeology: Looking forward. The African Archaeological Review, $8,3-22$.

Native American Graves Protection and Repatriation Action.

(1990). Native American Graves Protection and Repatriation Act. Retrieved April 1, 2018 from http://www.unesco.org/culture/natlaws/media/pdf/us a/usa_gravesprotectionact_1990_enorof.pdf. 
National Museums Liverpool.

(2017). Policies: Humans Remains. Retrieved April 12, 2018 from http://www. liverpoolmuseums.org.uk/about/corporate/policies/.

National Park Service.

(2018). Archaeology Program. Retrieved March 15, 2018 from https://www.nps. gov/archeology/tools/laws/nagpra.htm.

Natural History Museum.

(2015). The Museum in the First and Second World Wars. Retrieved April 18, 2018 from http://www.nhm.ac.uk/our-science/departments-and-staff/libr ary-and-archives/collections/world-wars.html.

Nicholson, E., \& Harvati, K.

(2006). Quantitative analysis of human mandibular shape using three-dimensional geometric morphometrics. American Journal of Physical Anthropology, 131(3), 368-383. https://doi.org/10.1002/ajpa.20425.

Niven, K., \& Richards, J. (Eds.).

(2017). The storage and long-term preservation of 3D data. London: Academic Press.

O’Higgins, P., Cobb, S., Fitton, L., Groning, F., Phillips, R., Liu, J., et al.

(2011). Combining geometric morphometrics and functional simulation: an emerging toolkit for virtual functional analyses. Journal of Anatomy, 218, 3-15.

O’Higgins, P., \& Jones, N.

(1998). Facial growth in Cercocebus torquatus: An application of three-dimensional geometric morphometric techniques to the study of morphological variation. Journal of Anatomy, 193(2), 251-272.

Oonk, S., Slomp, C. P., \& Huisman, D. J.

(2009). Geochemistry as an aid in archaeological prospection and site interpretation: current issues and research directions. Archaeological Prospection, $16,35-51$.

Pajas, J. A., \& Olivam, A. S.

(2009). Assessment, dissemination and standardization of geometric data recording of Archaeological Heritage obtained from 3D laser scanning. Virtual respect, 4, 187-193.

Palmer, A.

(2015). Untouchable: Creating desire and knowledge in Museum costume and textile exhibitions. The Journal of Dress, Body and Culture, 12(1), 31-63.

Pelfer, G., \& Pelfer, P. G.

(2003). From WEB to GRID, a new perspective for archaeology. In Nuclear science symposium conference record (Vol. 2, pp. 834-837). 
Perez, I.

(2007). Artificial cranial deformation in South America: A geometric morphometrics approximation. Journal of Archaeological Science, 34(10), 16491658.

Ponce De León, M., \& Zollikofer, C.

(1999). New evidence from Le Moustier 1: Computer-assisted reconstruction and morphometry of the skull. The Anatomical Record, 254(4), 474-489.

Resta, P., Roy, L., de Montano, M. K., \& Christal, M.

(2001). Digital Repatriation: virtual museum partnership with indigenous peoples. In Proceedings of the International Conference on Computers in Education (Vol. 2, pp. 1482-1483).

Richtsmeier, J. T., Burke Deleon, V., \& Lele, S. R.

(2002). The promise of geometric morphometrics. American Journal of Physical Anthropology, 119(S35), 63-91. https://doi.org/10.1002/ajpa.10174.

Rohlf, F. J.

(1999). Shape statistics: Procrustes superimpositions and tangent spaces. Journal of Classification, 16, 197-223. https://doi.org/10.1007/s003579900054.

(2002). Geometric morphometrics and phylogeny. In N. MacLeod \& P. Forey (Eds.), Morphology, shape and phylogeny. London: CRC Press.

Ross, A. H., \& Williams, S.

(2008). Testing repeatability and error of coordinate landmark data acquired from crania. Journal of Forensic Sciences, 53(4), 782-785. https://doi.org/ 10.1111/j.1556-4029.2008.00751.x.

Rowe, J., Razdan, A., Collins, D., \& Panchanathan, S.

(2002). A 3D digital library system: Capture, analysis, query, and display. In Proceedings 4th International Conference on Asian Digital Libraries (ICADL), Bangalore, India (pp. 149-159).

Schurmans, U., Razdan, A., Simon, A., Marzke, M., McCartney, P., Alfen, D., Jones, G., Zhu, M., Liu, D., Bae, M., Rowe, J., Farin, G., \& Collins, D.

(2002). Advances in geometric modeling and feature extraction on pots, rocks and bones for representation and query via the internet. Paper presented at the Computer Applications and Quantitative Methods in Archaeology (CAA).

Sholts, S. B., Flores, L., Walker, P. L., \& Wärmländer, S. K. T. S.

(2011). Comparison of coordinate measurement precision of different landmark types on human crania using a 3D laser scanner and a 3D digitiser: Implications for applications of digital morphometrics. International Journal of Osteoarchaeology, 21(5), 535-543.

Sketchfab.

(2016). Sketchfab. Retrieved April 12, 2018 from https://sketchfab.com/. 
Slizewski, A., Friess, M., \& Semal, P.

(2010). Surface scanning of anthropological specimens: nominal-actual comparison with low cost laser scanner and high end fringe light projection surface scanning systems. Quartär, 57, 179-187.

Smithsonian National Museum of Natural History.

(2016). 3D Collection. Retrieved April 12, 2018 from http://humanorigins.si.edu/ evidence/3d-collection.

Solly, M.

(2017). This Replica of a Tlingit Killer Whale Hat is Spurring Dialogue About Digitisation. Retrieved April 12, 2018 from https://www.smithsonianma g.com/smithsonian-institution/replica-tlingit-killer-whale-hat-spurring-di alogue-about-digitisation-180964483/.

Terhune, C., Kimbel, W., \& Lockwood, C.

(2007). Variation and diversity in Homo erectus: a 3D geometric morphometric analysis of the temporal bone. Journal of Human Evolution, 53(1), 4160.

Thompson, E.

(2017). Legal and Ethical Considerations for Digital Recreations of Cultural Heritage. Chapman Law Review, 20, 153-176.

Viðarsdóttir, U., O’Higgins, P., \& Stringer, C.

(2002). A geometric morphometric study of regional differences in the ontogeny of the modern human facial skeleton. Journal of Anatomy, 201(3), 211229.

Villa, C., Gaudio, D., Cattabeo, C., Buckberry, J., Wilson, A., \& Lynnerup, N.

(2017). A comparison of 3D models generated from three laser scanners. Paper presented at the American Association of Physical Anthropologists, New Orleans.

von Cramon-Taubadel, N., Frazier, B. C., \& Lahr, M. M.

(2007). The problem of assessing landmark error in geometric morphometrics: Theory, methods, and modifications. American Journal of Physical Anthropology, 134(1), 24-35. https://doi.org/10.1002/ajpa.20616.

Waddell, P.

(2014). Extended distance-based phylogenetic analyses of 3D hominin skull evolution. arXiv (Quantitative Biology), 15010019, 1-42.

Weinberg, S.

(2006). Anthropometric precision and accuracy of digital three-dimensional photogrammetry: Comparing the Genex and 3dMD imaging systems with one another and with direct anthropometry. The Journal of craniofacial surgery, 17(3), 477-483. 
Weinberg, $M$.

(2015). 3D scanned statue copyright debacle: How a university got it wrong. Makenzine. Retrieved October 21, 2017 from https://makezine.com/2015/01/23/3dscanned-statue-copyrightdebacle-how-a-university-got-it-wrong/.

Weiss, E.

(2001). Kennewick Man's Funeral: The Burying of Scientific Evidence. Association for Politics and the Life Sciences, 20(1), 13-18.

Whittaker, D. K., \& Molleson, T.

(1996). Caries prevalence in the dentition of a late eighteenth century population. Archives of Oral Biology, 41(1), 55-61.

Wilkinson, C., \& Neave, R.

(2003). The reconstruction of a face showing a healed wound. Journal of Archaeological Science, 30(10), 1343-1348.

Wilkinson, C., Roughley, M. \& Macgregor, M.

(2017). The Face of Robert the Bruce. In BABAO Conference 2017. Liverpool.

Wilson, A.

(2014-16). Digitised diseases: Preserving precious remains. British Archaeology, 136, 36-41.

Ynnerman, A., Rydell, T., Antoine, D., Hughes, D., Persson, A., \& Ljung, P.

(2016). Interactive visulization of $3 \mathrm{D}$ scanned mummies at public venues. Communications of the ACM, 59(12), 72-81.

Zaimovic-Uzunovic, N., \& Lemes, S.

(2010). Influences of surface parameters on laser 3D scanning. Paper presented at the 10th international symposium on measurement and quality control.

Zelditch, M., Swinderski, D., \& Sheets, D.

(2012). Geometric morphometrics for biologists: a primer. San Diego: Elsevier Science Publishing Co Inc. 